\title{
Drilling Optimization on a New Vertical Exploration Well Designed for Niger Delta X-Field Reservoir
}

\author{
Patrick G.O Ossai $^{1^{*}}$, Princewill N. Ohia ${ }^{2}$, Ugochukwu I. Duru ${ }^{3}$ \\ ${ }^{1,2,3}$ Petroleum Engineers/Lecturers, Department of Petroleum Engineering, Federal University of Technology, \\ Owerri, Imo State, Nigeria
}

*Corresponding Author: Patrick G.O Ossai, Petroleum Engineers/Lecturers, Department of Petroleum Engineering, Federal University of Technology, Owerri, Imo State, Nigeria

\begin{abstract}
There is no drilling optimization without proper well planning. This research looked at optimal exploratory well design possibilities for two reservoirs (A and B) located within a Niger Delta X-Field, south of Nigeria. After much data analysis from both reservoirs the researchers concluded that reservoir $A$ is a gas reservoir and reservoir $B$ is an oil reservoir. Well design work was discontinued for reservoir $A$ (the gas reservoir) because there are no gas facilities in place to transport and distribute possible gas production. Our research team carried out further analysis and completed the well design for optimal oil production from reservoir B (the oil reservoir). This study is inclusive of graph(s), well design assumptions, relevant equations and applicable calculations used in generating our design results (as summarized in a table). Various schematics to illustrate our optimal well design are also provided.
\end{abstract}

Keywords: Well optimization design, optimal well design, Niger Delta, Oil reservoir, well design calculations

\section{INTRODUCTION}

There is no drilling optimization without proper well planning. So, what is well planning? Well planning is probably the most tasking aspect of a drilling engineer's job when considering drilling optimization. It will take the integration of engineering principles, corporate or personal philosophies, experience and expertise as factors. Though, well planning methods/practices varies within the drilling industry. But, the end drilling design must be a safely drilled minimum cost well that should satisfy the reservoir engineer's design for optimal production of oil and gas from the well drilled into the newly licensed Niger Delta-X field. Experienced well planners are usually armed with these three common traits:

- Experienced drilling engineers that have knowledge of how all areas of the drilling operation can be coordinated with ease.

- She/he uses available engineering tools like computers and third-party recommendations as a guide for developing the well plan.

- Finally, he/she must have an investigative intuition that motivates him/her towards researching and reviewing every aspect of the well. This has the potential of eliminating, isolating and removing possible problem areas.

\subsection{An Overview on Well Planning Process}

Well planning is an established and organized orderly process. It is expedient that basic aspects of the plan be put in place before designing other areas. For instance, the mud density/weight plan must be designed before the casing plan since mud weight(s) has an impact on pipe demands. The aspect of bit programming can be carried out any time in the well planning phase provided the historical data(s) from the field has been properly analyzed. Such bit programs are commonly generated from drilling parameters gathered from offset wells. Although, selecting the right bit for the design can be affected too by the mud plan (like the performance of a polycrystalline-diamond (PCD) bit in oil-mud). However, the casing and tubing plan can be implemented as an integral part of the drilling design plan (a fact that is importantly valid for production casing plan). A criterion for consideration during 
tubing design is the drift diameter of the production casing. But, the packer to tubing stresses generated by possible tubing movement can potentially affect the production casing (Well Engineering and Construction textbook).

\subsection{What Are The Objectives Of Planning This Well?}

The objective(s) of planning the proposed new vertical exploration well in the newly licensed Niger Delta-X field reservoir is to put in place from numerous variables a design program/plan for drilling a well that has the following characteristics:

- A well that must be safe

- Designed at minimum cost to

- Produce oil and gas at optimal capacities

All the same, it is not usually possible to accomplish these objectives for every exploration well due to formation geology, drilling equipment, temperature, casing limitations, hole-sizing, and budget limitations. But our aim/objectives and end results was to safely drill a minimum cost hole that must satisfy the reservoir engineering team of the Nigeria Petroleum Development Corporation's (NPDC) requirements for oil and gas production in Niger Delta, South of Nigeria. It is important to emphasize here that achieving a minimum cost-hole that can produce optimally must not come at the expense of the safety of drilling personnel and the environment.

\subsection{Well Type Classification}

As a drilling engineer you are required to plan different well types such as:

- Wildcats: This are wells drilled with poor geological information

- Exploratory holes: This wells are also drilled relying on seismic data obtained

- Step-outs: Such wells are drilled after exploratory outcomes

- In-fills: Wells are drilled based on production zones

- Re-entries: Existing well(s) are re-entered for various reasons like deepening it, side-tracking etc. It requires tremendous planning and proper execution.

Wildcats need careful planning than the other types. Whereas, in-fill well and re-entries requires less planning most times (Martin et al., 2012).

\subsection{Formation Pressure(S)}

Drilling engineers know too well that formation pore pressures encountered greatly influences well plan. These formation pore pressures are:

- Normal: Normal pressured wells do not commonly create planning issues for drilling engineers. Usually, the mud densities are in the range of 8.5 to $9.5 \mathrm{lbm} /$ gal. Kicks or blowout-prevention (BOPs) issues can be minimized but not eliminated completely as the case may be. Note that for wells with depth greater than 20,000ft casing demands can be an issue even for a normal pressured well due to tension / collapse design limitations.

- Abnormal: This type of pressures is known to adversely affect well planning in many areas like casing and tubing design, mud weight and type selection, casing setting-depth selection, and cement planning. Drilling engineers also take into serious consideration the following issues due to high formation pressures. Problems like kicks and blowouts, differential pressure pipe sticking, lost circulation resulting from high mud densities, and heaving shale.

- Subnormal: It requires setting more casing strings to take care of weaker or low pressured zones. Such unusually subnormal pressures commonly results from geological, tectonic factors or pressure depletion from producing intervals.

\section{WeLl DESIGN CHARACTERISTICS}

Who can design a well to produce optimally without taking into account well design characteristics? Therefore, the drilling engineer must first and foremost pursue the different types of data available to him/her to gain insight needed to develop the projected drilling conditions. 


\subsection{Offset Well Selection Criteria(S)}

Drilling engineers are not saddled usually with the task of selecting well sites. But, they must work along with geologists for the following reasons to:

- Develop better knowledge and understanding of the expected drilling geology conditions.

- Define fault block structures to help select offset wells similar in nature to the prospect well.

- Identify possible geological anomalies that might be encountered during the drilling stage.

A close working relationship between drilling and geology groups can be the difference between a producer and an abandoned well (Drilling Engineering textbook).

\subsection{Data Source Identification}

Common data types used by drilling engineers are:

- Bit: It contains data relative to the actual on-bottom drilling operations

- Mud: Describes the physical and chemical characteristics of the mud system such as mud weight, mud $\mathrm{pH}$, funnel viscosity, plastic viscosity, yield point, gel strength, mud chloride/calcium contents, solid content, cat-ion exchange capacity and fluid losses.

- Mud-logs: A mud log is a foot-by-foot record of drilling, mud, and formation parameters

- Operator's drilling records

- IADC reports (International Association of Drilling Contractors): It contains hourly reports for drilling operations, drill string properties, mud properties, bit performance, and time break-downs for all operations.

- Scout tickets: Current scout tickets contain a brief summary of the well data/parameters like well name, location and operator, spud/completion dates, casing geometries/cement volumes, production test data, completion information, and tops of various geological zones.

- Log headers: This contains logging depths, mud weight and viscosity at each logging depth, bit sizes, inferred casing sizes, and actual setting depths.

- Production history: It provides clues to issues that may be encountered in the prospect well.

- Seismic studies: A good agreement on the pore pressures can be attained with seismic and sonic$\log$ data.

- Well surveys

- Geological contours

- Data bases of service company files.

\section{Well DeSign CALCUlations For Niger Delta X-Field RESERVOIR}

\subsection{Pore and Fracture Pressure Consideration}

Fracture pressure is that pressure needed to cause a formation to fail or split. What this means is that it is the pressure that causes the formation to fracture and the circulating fluid lost in the process. It is usually expressed as a gradient with units in $\mathrm{psi} / \mathrm{ft}(\mathrm{kPa} / \mathrm{m})$ or $\mathrm{ppg}(\mathrm{kg} / \mathrm{m} 3)$. The reliability and success of a casing design is greatly depended on the formation pore pressure. Proper determination /utilization of the formation pore and fracture gradients at the design stage of the well can prevent or control outcomes like fluid kicks, lost circulation, surface blowouts and underground blowouts (Nguyen et al., 1999).

\subsubsection{Pore Pressure Determination}

Considering available data(s) from the Niger Delta X-field reservoir we have that:

\section{For Pore Pressure Data}

Surface to 4,000 ft at normal pressure $=8.9 \mathrm{ppg}$, Equivalent Mud Weight (EMW)

At $9,000 \mathrm{ft}$ the pore pressure is expected to rise to $10.5 \mathrm{ppg}$ (EMW)

From 9,000 ft to $11,750 \mathrm{ft}$ (TD) the pore pressure is constant at $10.5 \mathrm{ppg}$ (EMW) 
Figure 1.0 and Table 1.0 below illustrate the relationship of Depth and Equivalent Mud Weight.

Table1.0. Pore Pressure data(s)

\begin{tabular}{|c|c|}
\hline DEPTH $(\mathrm{ft})$ & EMW (ppg) \\
\hline 4,000 & 8.9 \\
\hline 9,000 & 10.5 \\
\hline 11,750 & 10.5 \\
\hline
\end{tabular}

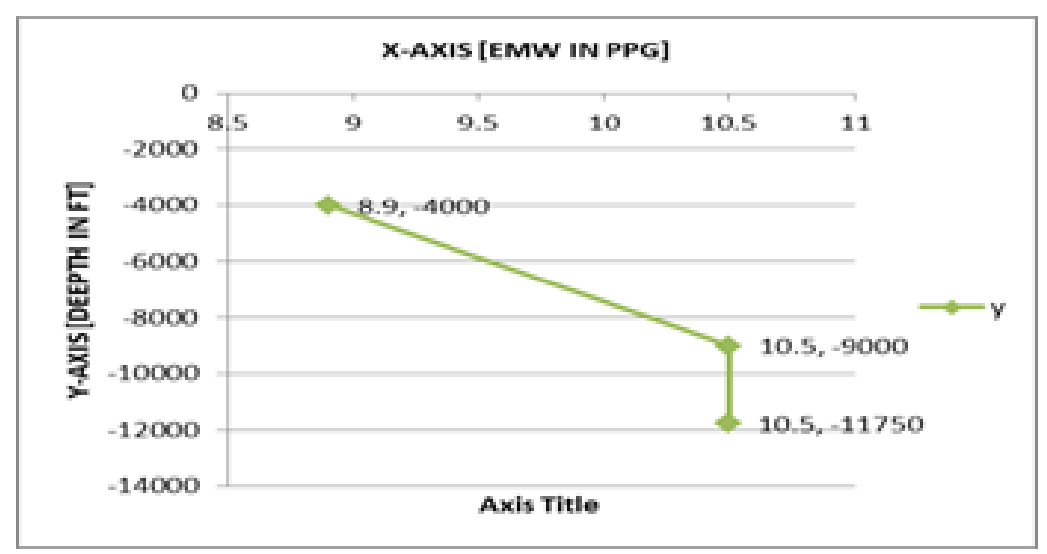

Fig1.0. Graph of Depth (ft) against Equivalent Mud Weight, EMW (ppg)

Pore Pressure $(\mathrm{Pp})=0.052 \times$ EMW $(\mathrm{ppg}) \times$ Depth $(\mathrm{ft})$

Therefore:

At 4,000ft and 8.9ppg (EMW), Pore Pressure, $P_{p}=0.052 \times 8.9 \times 4,000=1851 \mathrm{psi}$

At 9,000ft and 10.5ppg (EMW), Pore Pressure, $P_{p}=0.052 \times 10.5 \times 9,000=4914 p s i$

At $11,750 \mathrm{ft}$ and $10.5 \mathrm{ppg}$ (EMW), Pore Pressure, $\mathrm{P}_{\mathrm{p}}=0.052 \times 10.5 \times 11,750=6416 \mathrm{psi}$

\subsection{Determination of the Mud Pit Capacity}

From available data we also have that:

\section{For Casing Data}

20 ” surface casing was set at $550 \mathrm{ft}$ below GL with a casing weight of $133 \mathrm{lb} / \mathrm{ft}, 13^{3 / 8 "}$ intermediate casing was also set at $4,000 \mathrm{ft}$ below GL with casing weight of $72 \mathrm{lb} / \mathrm{ft}, 9^{5 / 8 "}$ production casing set at $10,000 \mathrm{ft}$ below GL with casing weight of $54.5 \mathrm{lb} / \mathrm{ft}$, 7" production liner set at 12,000ft below GL.

Where:

GL $=$ Ground Level

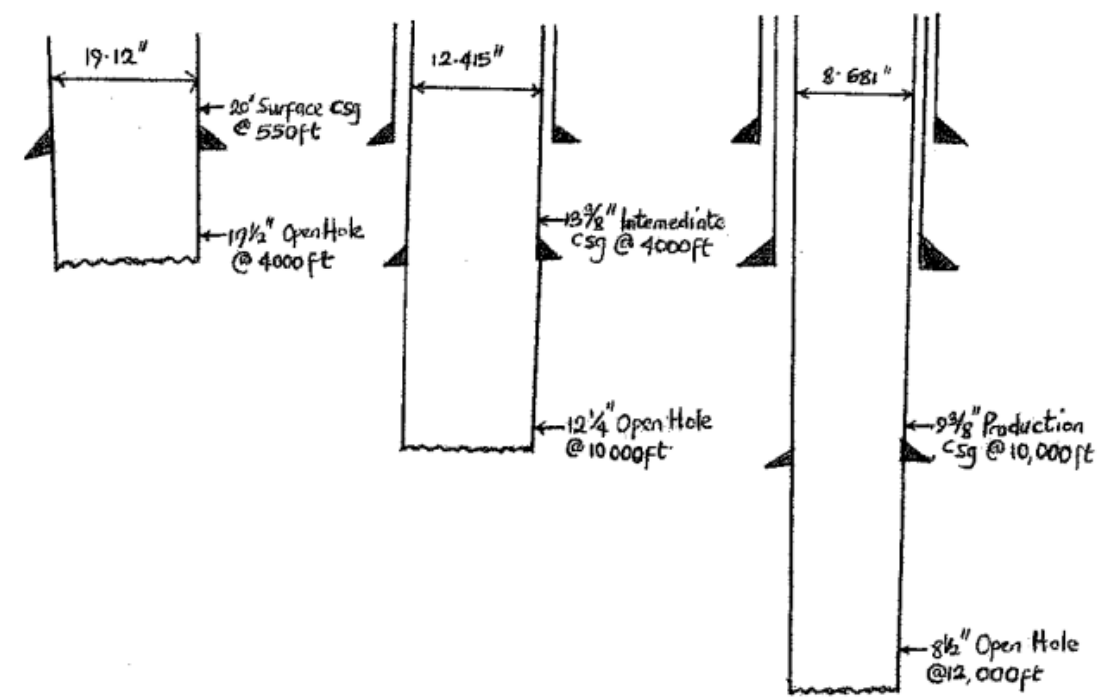

Fig2. Open hole well design schematics 
Casing or Open Hole Capacity $=\frac{(I . D)^{2}}{1029.4 \mathrm{bbl} / \mathrm{ft}}$

Casing or Open Hole Volume $=\frac{\text { Casing }}{\text { Open Hole Capacity x TVD }} 3.3$

Mud Pit Capacity = Casing Volume + Open Hole Volume + Open hole excess 3.4

\section{Considering 17.5" Open Hole:}

Casing Capacity $=(19.12)^{2} / 1029.4=0.355 \mathrm{bbl} / \mathrm{ft}$

Casing Volume $=0.355(\mathrm{bbl} / \mathrm{ft}) \times 550(\mathrm{ft})=195.3 \mathrm{bbls}$

Open Hole Capacity $=(17.5)^{2} / 1,029.4=0.298 \mathrm{bbl} / \mathrm{ft}$

Open Hole Volume $=0.298(\mathrm{bbl} / \mathrm{ft}) \times 3,450(\mathrm{ft})=1,028 \mathrm{bbls}$

$50 \%$ Open Hole Excess $=0.5 \times 1,028 \mathrm{bbl}=514 \mathrm{bbls}$

Total Open Hole Volume $=(514+1028)$ bbls $=1,542 \mathrm{bbls}$

Mud Pit Capacity at $4,000 \mathrm{ft}=(195.3+1,542) \mathrm{bbls}=1,737 \mathrm{bbls}$

\section{Considering 12.25" Open Hole:}

Casing Capacity $=(12.415)^{2} / 1,029.4=0.150 \mathrm{bbl} / \mathrm{ft}$

Casing Volume $=0.150 \times 4,000=598.9 \mathrm{bbls}$

Open Hole Capacity $=(12.25)^{2} / 1,029.4=0.146 \mathrm{bbl} / \mathrm{ft}$

Open Hole Volume $=0.146$ x 6,000 $=876 \mathrm{bbls}$

$25 \%$ Open Hole Excess $=0.25 \times 876=219 \mathrm{bbls}$

Total Open Hole Volume $=(219+876) \mathrm{bbls}=1,095 \mathrm{bbls}$

Mud Pit Capacity $=(598.9+1,095)$ bbls $=1,693.9 \mathrm{bbls}$

\section{Considering 8.5" Open Hole:}

Casing Capacity $=(8.681)^{2} / 1,029.4=0.073 \mathrm{bbl} / \mathrm{ft}$

Casing Volume $=0.073 \times 10,000=730 \mathrm{bbls}$

Open Hole Capacity $=(8.5)^{2} / 1,029.4=0.070 \mathrm{bb} / \mathrm{ft}$

Open Hole Volume $=0.070 \times 2,000=140 \mathrm{bbls}$

$10 \%$ Open Hole Excess $=0.1 \times 140=14 \mathrm{bbls}$

Total Open Hole Volume $=(14+140)$ bbls $=154 \mathrm{bbls}$

Mud Pit Capacity $=(154+730)$ bbls $=884 \mathrm{bbls}$

Therefore, Total Mud Pit Capacity $=(1,737+884+1,693)$ bbls $=4,316 \mathrm{bbls}$

\subsection{Down-hole Equipment Design for The Well}

We considered two reservoirs (reservoir A and B respectively) located within the Niger Delta X-Field. Details of both reservoirs are given below:

Reservoir A: Is at $10,500 \mathrm{ft}$ to $10,600 \mathrm{ft}$. It was identified as a gas reservoir (containing basically methane with a gas gradient of $0.12 \mathrm{psi} / \mathrm{ft}$ ). Since there are no means of evacuating or exporting any gas produced from this gas reservoir for possible utilization (as in power plant gas turbines) as gas fuel. No further exploratory well design was carried out. Hence, we moved on to consider reservoir B.

Reservoir B: Is at $11,000 \mathrm{ft}$ to $11,750 \mathrm{ft}$. This is the primary oil reservoir, and will provide the initial production from the Niger Delta X-Field.

Figure 2.0 below illustrates the exploratory well design schematic for the well to be drilled in the Niger Delta X-Field resrvoir. 


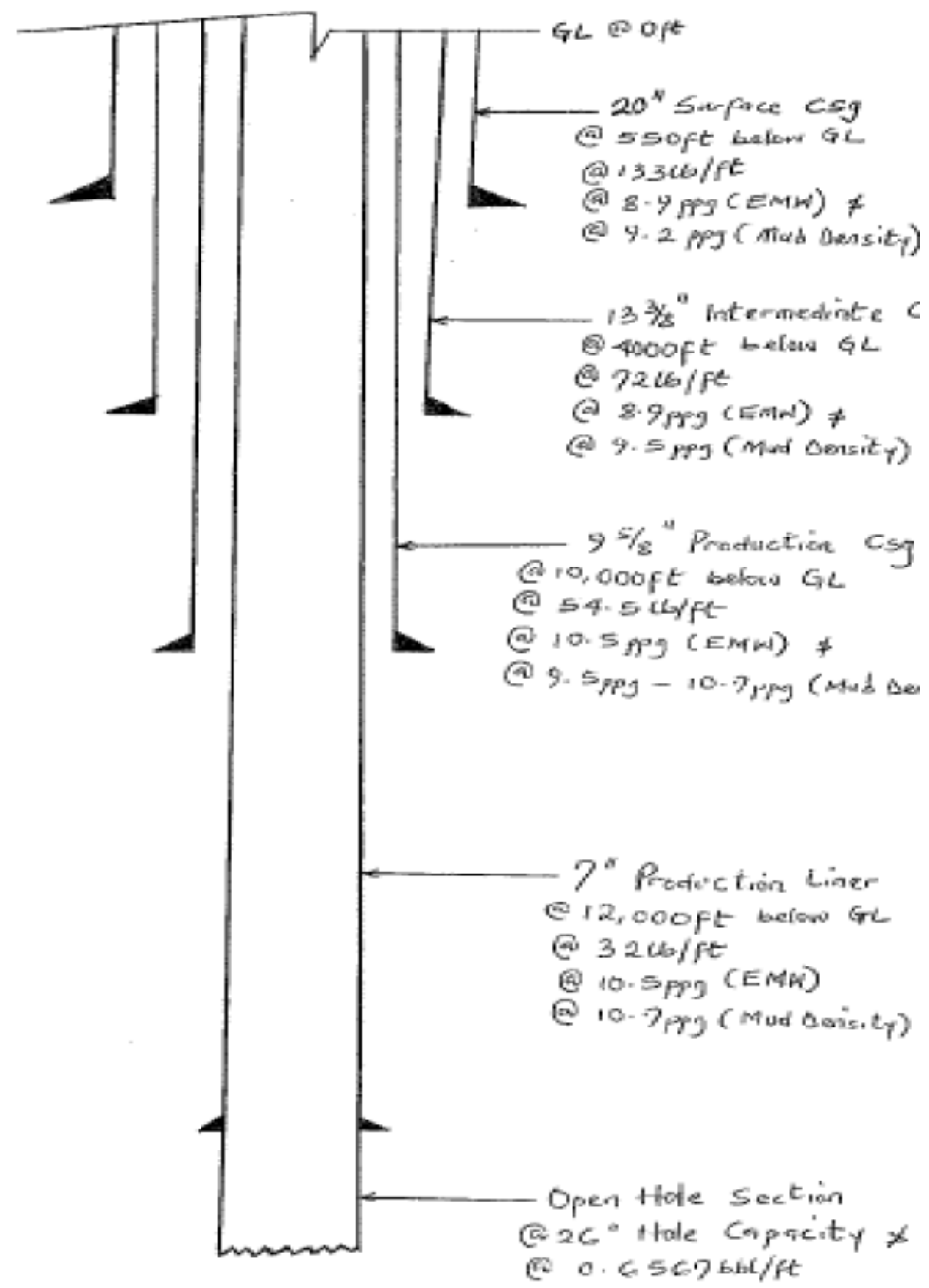

Fig3. The Exploratory Well design schematics for reservoir B located in the Niger Delta X-Field

\subsubsection{Pressure Calculations}

At a Total depth (TD) of 11750ft and a Mud Weight of 10.5ppg

Therefore, Pressure Exerted, $\mathrm{P}=0.052 \times$ Mud Weight $\mathrm{x}$ Total Depth (TD)

Hence, $\mathrm{P}=0.052 \times 10.5 \times 11,750=6,416 \mathrm{psi}$

\subsubsection{Drill String and Bottom Hole Assembly (Bha) Calculations}

\section{Buoyancy Factor (BF) of the mud weight}

Buoyancy Factor, $\mathrm{BF}=1-\frac{10.5}{65.5}=0.8397$

\section{Collar Length needed to achieve desired weight on bit (WOB)}

Weight on bit, $\mathrm{WOB}=50 \mathrm{kips}$, Safety Factor $=0.85$

Drill Collar weight $(8$ in $\times 3$ in $)=147 \mathrm{lb} / \mathrm{ft}$

Assumed Stiffness Ratio (SR) $=3.5$

Length of Bottom Hole Assembly, LBHA $=\frac{50 \times 1,000}{0.85 \times 0.8397 \times 147}=476.6 \mathrm{ft}$

Therefore, LBHA is approx. $477 \mathrm{ft}$

Maximum Length of Drill Pipe needed with BHA is given by:

$\mathrm{L}_{\max }=\left(\frac{\left(T S\left(1-F_{d p}\right)-M O P-W_{B H A}\right) B F}{W d_{P}}\right)$

Where: 
$\mathrm{L}_{\max }=$ Maximum length of drill pipe that can be run into the hole with a specific BHA in feet,

$\mathrm{TS}=$ Tensile strength for new drill pipe (lb)

$\mathrm{F}_{\mathrm{dp}}=$ Safety factor to correct new drill pipe

MOP = Margin of over-pull (lb)

$\mathrm{W}_{\mathrm{BHA}}=$ Weight of the Bottom Hole Assembly (lb),

$\mathrm{W}_{\mathrm{dp}}=$ Weight of drill pipe with tool joint $(\mathrm{lb} / \mathrm{ft})$.

Drill Pipe to be used $=\mathrm{G} 105$ at $19.5 \mathrm{lb} / \mathrm{ft}$

Tensile Strength of new pipe, TS $=553,800 \mathrm{lb}$

Safety Factor to correct drill pipe, $\mathrm{F}_{\mathrm{dp}}=10 \%$

Assumed Desired Over-pull, $(\mathrm{MOP})=100,000 \mathrm{lb}$

Weight of BHA, (WBHA) $=50,000 \mathrm{lb}$

BHA Length $=477 \mathrm{ft}(\mathrm{LBHA})$

Weight of drill pipe with tool joint, $(\mathrm{Wdp})=19.5(\mathrm{lb} / \mathrm{ft})$

Buoyancy Factor, $(\mathrm{BF})=0.8397$

Hence,

Maximum Length of Drill Pipe needed with the BHA is:

$\mathrm{L}_{\max }=\left(\frac{(553,800(1-0.1)-100,000-50,000) X 0.8397}{19.5}\right)=15,003.5(\mathrm{ft})$

Therefore, the Maximum Length of Drill Pipe, Lmax is approx. 15,004ft

Total Depth that can be reached with a Specific BHA in $\mathrm{ft}$ is given by:

$\mathrm{D}_{\mathrm{T}}=\mathrm{L}_{\max }+\mathrm{L}_{\mathrm{BHA}}$

Where:

$\mathrm{D}_{\mathrm{T}}=$ total depth that can be reached with a specific BHA in $\mathrm{ft}$,

$\mathrm{L}_{\mathrm{BHA}}=$ length of BHA to be run in $\mathrm{ft}$

Hence, $\mathrm{D}_{\mathrm{T}}=(15,004+477) \mathrm{ft}=15,481(\mathrm{ft})$

Assuming a drill collar joint $=30 \mathrm{ft}$

Then,

Number of Drill Collars (DCs) needed to make up the BHA is given by:

$\frac{L_{B H A}}{D C \text { joint }}=$ Number of Drill Collars needed to make up BHA

Number of DCs needed to make up BHA $=\frac{477 f t}{30 f t}=15.9$

Therefore, we will need approx. 16 DCs plus 1 drill jar and an additional 2 DCs (just in case). Hence, the BHA is made up of 19 units.

The complete BHA Design consists of the following units:

- 18 Drill Pipes

- 1 Drill Jar

- 3 Stabilizers

- 1 Float Sub 


\subsection{Summary of Well Design Results for the New Exploratory Well Located In the Niger Delta $\mathrm{X}$-Field}

Table2.0. Well Design Results In Summary

\begin{tabular}{|l|c|c|}
\hline \multicolumn{1}{|c|}{ Well Design Parameters (units) } & $\begin{array}{c}\text { Niger Delta X-Field } \\
\text { Reservoir A (Gas) }\end{array}$ & $\begin{array}{c}\text { Niger Delta X-Field } \\
\text { Reservoir B (Oil) }\end{array}$ \\
\hline Pore Pressure @ 4000ft, (psi) & 1,851 & 1,851 \\
\hline Pore Pressure @ 9000ft, (psi) & 4,914 & 4,914 \\
\hline Pore Pressure @ TD 1750ft, (psi) & - & 6,416 \\
\hline Total Mud Pit Capacity, (bbls) & - & 4,316 \\
\hline Length of BHA, (ft) & - & 477 \\
\hline Buoyancy Factor, BF & - & 0.8397 \\
\hline Max. Length Drill Pipes, $\mathrm{L}_{\max },(\mathrm{ft})$ & - & 15,004 \\
\hline Total BHA Depth, $\mathrm{D}_{\mathrm{T}},(\mathrm{ft})$ & - & 15,481 \\
\hline Total Drill Collars for BHA & - & 16 \\
\hline Total Drill Pipes Required & - & 18 \\
\hline Number of Drill Jar(s) Required & - & 3 \\
\hline Number of Stabilizer(s) Required & - & 1 \\
\hline Number of Float Sub(s) Required & & \\
\hline
\end{tabular}

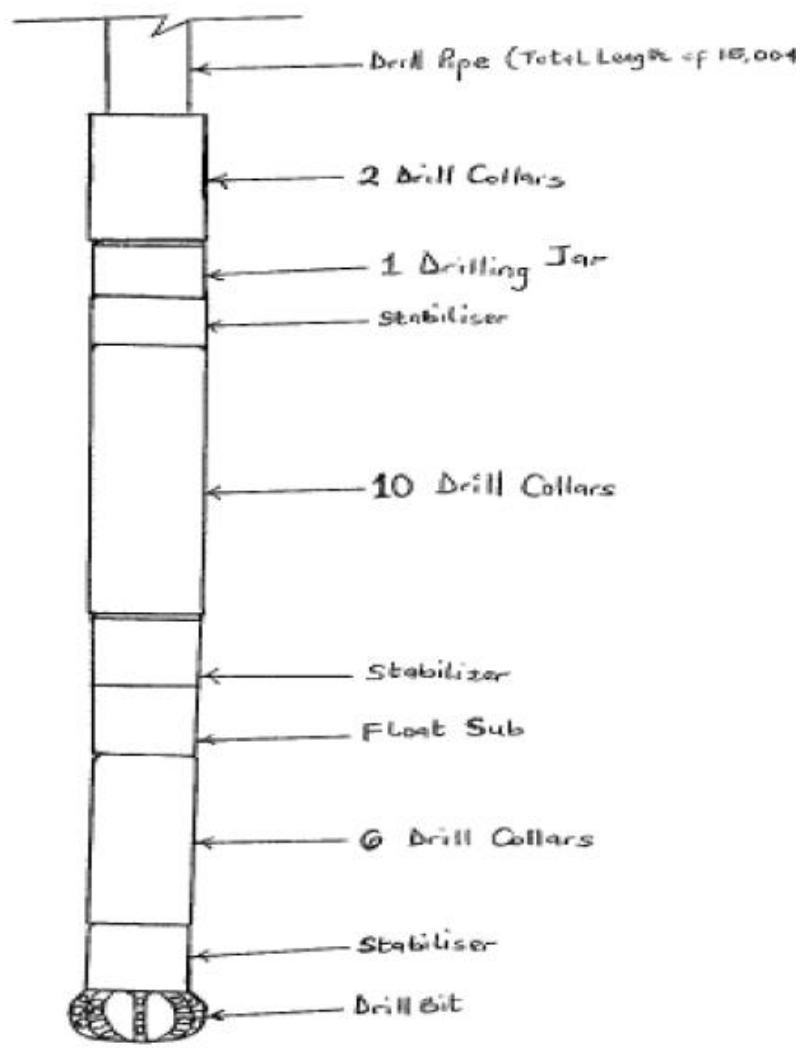

Fig4. The complete BHA Design schematics

\section{CONCLUSION/RECOMMENDATION}

The costs required to properly plan this new vertical exploratory well is insignificant in comparison to the actual drilling costs. In most cases, less than 1,000 U.S dollars is what is utilized in planning a well with a drilling cost of over 1,000,000 U.S dollars. This might only cover just one tenth of one percent of the entire well cost.

Although, many past instances can be used to illustrate that well planning costs were sacrificed or completely avoided in an effort to cut cost. Drilling companies are also reputed for cutting cost by minimizing data-collection work (even though good data can usually be obtained for small amount of money). This most times causes many well plans to be produced without the possible knowledge of drilling issues. Trying to play down expenditures during the early stages of well planning process can necessitate higher than anticipated drilling costs. 


\section{REFERENCES}

[1] Drilling Engineering textbook, Institute of Petroleum Engineering, Heriot-Watt University, USA

[2] Gabolde G, Nguyen J.P (1999): Drilling Data Handbook, $7^{\text {th }}$ edition, Editions Technips, Institut Francais du Petrole Publications, Paris, France

[3] Hussain Rabia: Well Engineering and Construction textbook

[4] Martin Klempa, Petr Bujok, Ludek Kovar \& Co: Fundamentals of Onshore Drilling textbook

\section{AUTHORS' BIOGRAPHY}

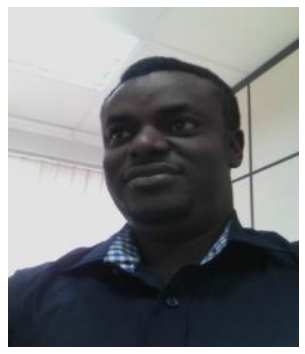

Patrick Godwin Oyindobra Ossai, is currently a post-graduate student at the Post Graduate School of Federal University of Technology Owerri located in Imo State, Nigeria. He holds a bachelors and masters of engineering degree (B.Eng, M.Eng) in Petroleum Engineering from the University of Benin and Federal University of Technology Owerri respectively. He holds a few seasoned international journal publications in enhanced heavy oil recovery, in-situ combustion applicability, Drilling optimization and well design. Patrick is also a seasoned oil logistics and QHSE expert with NEBOSH certifications. His field expertises are in the areas of Petroleum Engineering (EOR), Oil \& Gas logistics and QHSE. He is happily married with kids.

Ohia Nnaemeka Prince will,is a Senior Lecturer/Instructor with the Department of Petroleum Engineering, Federal University of Technology, Owerri. After spending over two decades teaching and consulting for both local \& international oil and gas companies working on multimillion dollar projects, Nnaemeka knows what truly drives performance, which is how well you connect with the people you're trying to help and communicate your understanding back to them. Nnaemeka's research interests in environmental protection, well engineering and production optimization has landed him with various certifications and awards around the world, including over 45 authored and co-authored journal publications to his credit. Today, Ohia is a member of notable professional bodies such as Council for Registered Engineers of Nigeria (COREN), Nigerian Society of Engineers (NSE) and Society of Petroleum Engineers. In addition to his extensive research, teaching and consulting experience, Nnaemeka is a trained technical coach. Nnaemeka holds a PhD in Petroleum Engineering from the Federal University of Technology, Owerri. (FUTO), Nigeria since 2012.

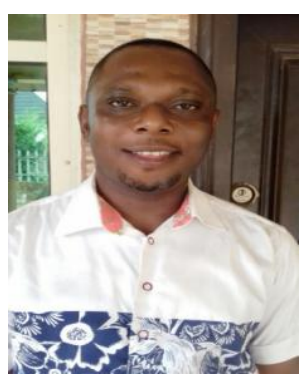

Ugochukwu Ilozurike Duru, Ph.D is currently a Lecturer in the Department of Petroleum Engineering, School of Engineering and Engineering Technology, Federal University of Technology, Owerri, Nigeria. Ugochukwu received his B.Eng (2000), M.Eng (2004) and Ph.D (2016) all in Petroleum Engineering from Federal University of Technology, Owerri (FUTO). He was an Adjunct Lecturer and pioneer Co-coordinator, Department of Petroleum Engineering, Madonna University, Elele (2008 - 2010). Ugochukwu was a PTDF scholar at African University of Science and technology, Abuja between 2012 and 2014. $\mathrm{He}$ is registered with Council for Regulation of Engineering in Nigeria (COREN) and holds membership of several professional bodies. His research interests are Multiphase Flow in Pipes, Flow Assurance, Well Engineering, Fluid Hydraulics, Oil and Gas (Energy) Economics and Petroleum Production Enhancement. Ugochukwu counts with journal and conference papers in his area of interest.

Citation: Patrick G.O Ossai, et.al. (2018). Drilling Optimization on a New Vertical Exploration Well Designed for Niger Delta X-Field Reservoir, International Journal of Petroleum and Petrochemical Engineering (IJPPE), 4(2), pp.44-52, DOI: http://dx.doi.org/10.20431/2454-7980.0402006

Copyright: () 2018 Patrick G.O Ossai. This is an open-access article distributed under the terms of the Creative Commons Attribution License, which permits unrestricted use, distribution, and reproduction in any medium, provided the original author and source are credited 